\title{
Detection of Brucella abortus DNA in aborted goats and sheep in Egypt by real-time PCR
}

\author{
Gamal Wareth ${ }^{1,2,3^{*}}$, Falk Melzer ${ }^{1}$, Herbert Tomaso ${ }^{1}$, Uwe Roesler ${ }^{2}$ and Heinrich Neubauer ${ }^{1}$
}

\begin{abstract}
Background: Brucellosis is a major zoonoses affects wide range of domesticated as well as wild animals. Despite the eradication program of brucellosis in Egypt, the disease is still endemic among cattle, buffaloes, sheep, goats, and camels.

Results: In the present study, abortion occurred naturally among 25 animals (10 cows, 5 buffaloes, 9 Egyptian Baladi goats and 1 ewe) shared the same pasture were investigated by real-time polymerase chain reaction (RT-PCR). DNA of Brucella (B.) abortus was detected in serum of goats and sheep which has aborted recently by species-specific RT-PCR. The results suggest cross-species infection of $B$. abortus from cattle to non-preferred hosts raised in close contact.

Conclusion: This article will renew our knowledge about the Brucella agent causing abortion in small ruminants in Egypt. Information provided in this study is important for surveillance program, because eradication programs and vaccination strategies may have to be adapted accordingly.
\end{abstract}

Keywords: Brucella abortus, Cross-species transmission, Real-time PCR, Small ruminants

\section{Background}

Brucellosis is a serious zoonosis transmitted by direct contact to secretions of animals which have aborted or contaminated dairy products [1]. The genus Brucella $(B$.) is a facultative intracellular pathogen that currently includes 11 accepted nomo-species. Based on the primary host species specificity. The 'classical' six species are B. melitensis, B. abortus, B. suis, B. canis, B. ovis, and B. neotomae which are primarily isolated from small ruminants, bovines, pigs, dogs, sheep and desert wood rats, respectively [2]. Two species of marine origin (B. pinnipedialis from seals, and $B$. ceti from dolphins and whales). B. microti was isolated from the common vole Microtus arvalis in middle Europe [3, 4]. B. inopinata was isolated from a breast implant wound of a North American

\footnotetext{
*Correspondence: gamalwareth@hotmail.com

${ }^{1}$ Friedrich-Loeffler-Institut, Federal Research Institute for Animal Health, Institute of Bacterial Infections and Zoonoses, Naumburger Str. 96a, 07743 Jena, Germany

Full list of author information is available at the end of the article
}

female patient [5]. Recently, B. papionis was isolated from baboons (Papio spp.) [6].

In Egypt, brucellosis is still endemic and infects a wide range of animal species causing tremendous economic losses [7]. B. melitensis was isolated from cattle, buffalo, sheep, goat and Nile catfish in the past $[8,9]$. In contrast, $B$. abortus was isolated from cattle, buffalo and camel [10-12], but was not recorded in small ruminant [13]. Host specificity of Brucella pathovars has been recognized for a long time and was used to phenotype isolates in the past. Goats and sheep are considered the classical and preferred hosts for B. melitensis. The clinical, pathological and epidemiological picture of caprine brucellosis due to $B$. melitensis is similar to $B$. abortus infection in cattle [1]. Due to existence of mixed livestock shelters and uncontrolled animal flock movements in Egypt [8], it was considered necessary to investigate the ability of Brucella isolates to be transmitted to and replicate outside its preferred host species in field conditions. Therefore, the present study was performed to investigate whether interspecies transmission of $B$. abortus may occur naturally and may cause clinical disease in small ruminants. 
This is of important once, because current eradication programs and vaccination strategies may have to be adapted if trans-species infections play a relevant role.

\section{Results}

A storm of abortion occurred naturally among ten cows (Bos taurus), five buffaloes (Bupalus bubalis), nine Egyptian Baladi goats (Capra hircus) and one ewe (Ovis orientalis aries). Aborted animals submitted to veterinary clinic after abortion for diagnosis and treatment in a small village at Minufya governorate, Delta region, Egypt. All aborted animals shared the same pasture, but were owned by different peasants from neighboring localities. Serum samples were collected from animals after receiving permission from the owners. Samples from aborted fetus were not available. Sera were analyzed using the rose bengal test (RBT), the complement fixation test (CFT) and enzyme linked immunosorbent assay (ELISA) (IDEXX Brucellosis serum X2 AB test, Montpellier SAS, France).

Genomic DNA was extracted with the High Pure template preparation kit (DNA HP kit, Roche Applied Sciences, Mannheim, Germany) according to the manufacturer's instructions. Specific real-time PCR assays for genus and species described by Probert et al. were performed in single runs [14]. The primers and probes were obtained from TIB MOLBIOL (Berlin, Germany) (Table 1). Each amplification reaction mixture was contained $0.75 \mu \mathrm{l}$ of each primer $(0.3 \mu \mathrm{M}), 12.5 \mu \mathrm{l} \mathrm{TaqMan}{ }^{\mathrm{mm}}$ Universal Master Mix (Applied Biosystems, USA), $0.25 \mu \mathrm{l}$ probe $(0.1 \mu \mathrm{M}), 2 \mu \mathrm{l}$ of DNA template and was filled up to a total volumes of $25 \mu \mathrm{l}$ with HPLC grade water. Positive controls that contained Brucella DNA and no template controls (NTC) that contained PCR-grade water instead of DNA were used in all assays. Real-time-PCR assays were performed with the following cycling conditions, decontamination at $50^{\circ} \mathrm{C}$ for $2 \mathrm{~min}$, one cycle with initial denaturation at $95^{\circ} \mathrm{C}$ for $10 \mathrm{~min}$, and 50 cycles with $95^{\circ} \mathrm{C}$ for $25 \mathrm{~s}$ and $57^{\circ} \mathrm{C}$ for $1 \mathrm{~min}$. All samples were tested in duplicates; cycle threshold (ct) values below 40 cycles were interpreted as positive.

Serum samples collected very recently after abortion from four buffaloes and six goats gave negative results in serology. Contrastingly, samples collected 3 weeks after abortion produced strong positive reactions in RBT, CFT and ELISA. Real time-PCR assays resulted in a higher numbers of positive cases than serology. All examined serum samples $(n=25)$ revealed positive results in PCR, while only ten samples were positive in serology (Figure 1). All serum samples collected from aborted cows $(n=10)$, buffaloes $(n=5)$, ewe $(n=1)$ and goats $(\mathrm{n}=9)$ were positive with the genus specific bcsp31 realtime PCR assays. Interestingly, B. abortus DNA was identified in all serum samples collected from cows, buffaloes, ewe and goats. It is worth mentioning that one ovine serum contained both, B. abortus and B. melitensis DNA (Table 2). Bacterial isolation failed to isolate Brucella.

\section{Discussion}

In developing countries such as Egypt, conventional tests done on serum are used for screening of brucellosis and play an important role in surveillance programs of the disease [13]. Based on previous publication about brucellosis in Egypt, this study is the first to record B. abortus DNA in sera samples of sheep and goat. Brucella organisms were not isolated in this study. Brucella culturing is hazardous, and the technique is restricted to few laboratories in Egypt. Isolation rate is very low even in experienced laboratories [13]. The probability of successful isolation of $B$. abortus is markedly reduced when a few organisms are present in the samples or the material is heavily contaminated. Negative culture results cannot exclude infection with Brucella [15]. Nevertheless, clinical presentation i.e. abortion and strong

Table 1 Primers and specific probes used in the real-time multiplex PCR assay for the detection of Brucella spp., B. abortus, and B. melitensis

\begin{tabular}{lll}
\hline PCR Identification & Primer and probe & \\
\hline Brucella spp. & Forward primer 5'-3' & GCT-CGG-TTG-CCA-ATA-TCA-ATG-C \\
& Reverse primer 5'-3' & GGG-TAA-AGC-GTC-GCC-AGA-AG \\
B. abortus & Probe 5'-3' & 6FAM-AAA-TCT-TCC-ACC-TTG-CCC-TTG-CCA-TCA-BHQ1 \\
& Forward primer 5'-3' & GCG-GCT-TTT-CTA-TCA-CGG-TAT-TC \\
& Reverse primer 5'-3' & CAT-GCG-CTA-TGA-TCT-GGT-TAC-G \\
B. melitensis & Probe 5'-3' & HEX-CGC-TCA-TGC-TCG-CCA-GAC-TTC-AAT-G-BHQ1 \\
& Forward primer 5'-3' & AAC-AAG-CGG-CAC-CCC-TAA-AA \\
& Reverse primer 5'-3' & CAT-GCG-CTA-TGA-TCT-GGT-TAC-G \\
& Probe 5'-3' & Cy5-CAG-GAG-TGT-TTC-GGC-TCA-GAA-TAA-TCC-ACA-BHQ2 \\
\hline
\end{tabular}




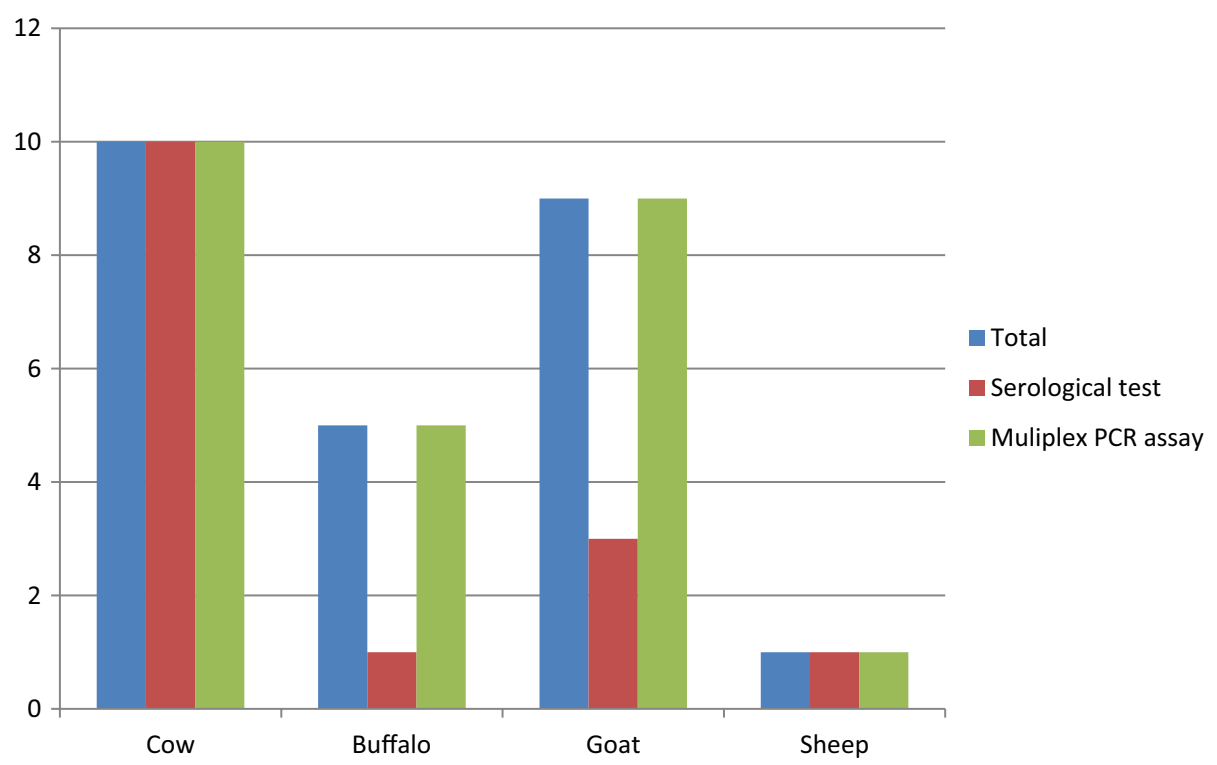

Figure 1 Serological and Multiplex PCR assay result in cow, buffalo, goat and sheep.

seropositive results finally led to the diagnosis of brucellosis. Serological diagnosis from freshly aborted animals may fail because antibody titers against $B$. abortus rise only 1-2 weeks after infection [16], however circulating Brucella DNA may be detected with molecular techniques. These facts can explain the absences of antibody titres in some animals. Serological diagnosis of brucellosis is presumptive evidence of infection and laboratory confirmation of brucellosis requires isolation of bacteria or detection of Brucella DNA by PCR. Thus, the diagnostic window of Brucella serology should be complemented by bacteriological or molecular diagnosis [17]. PCR assay able to detect Brucella DNA in seronegative animals and it was proposed to use PCR even as a tool for routine diagnosis [18]. Our results corroborate this proposal.

All Brucella species are closely related and can be considered as pathovars of a single species [19]. Thus, it is not unexpected that host specificity of Brucella spp. is not 'absolute' but 'relative' [1]. Although ruminants in general are susceptible to $B$. abortus, the infection in small ruminants is rare [1]. Experimental infection of pregnant ewes with $B$. abortus produced late term abortions. The aborted ovine fetuses developed lesions due to systemic infections similar to those reported in bovine fetuses after natural and experimental infections [20]. B. abortus infections have been reported in sheep in the USA [21], in Nigeria [22, 23] and in Iran [24]. The protective efficacy of vaccines against $B$. abortus infections has not been studied in small ruminants and may play a role for the persistence of brucellosis in cattle $[1,25,26]$. In Egypt, B. abortus bv one and three have been reported in cattle and buffaloes [12, 27]. Cross species transmission of B. melitensis to cattle and buffalo from small ruminants that shared the same stables and farmyards was recognized in Egypt [10, 28, 29]. Recently, B. melitensis DNA was also detected in milk samples collected from apparently healthy cattle and buffaloes by real-time PCR [30]. However, no reports could be found that B. abortus or its DNA was ever found in small ruminants in Egypt. To the best of our knowledge; this is the first report of sheep and goat brucellosis caused by B. abortus in Egypt. Accidental B. abortus infections in small ruminants may even play an understanding role for the persistence of brucellosis in cattle [1].

Detection of both, B.abortus and B.melitensis DNA, in one animal observed in this study demonstrated that one host can be infected with two different species of Brucella at the same time. The potential host range of Brucellae may also depend on breeding conditions [19]. Co-habitation and close contact of different animal species increase the risk of a pathogen to cross the species barrier [31]. Infection of small ruminants with B. abortus can occur as result of natural exposure to infected materials from another species or indirectly through contact with soil contaminated with abortion secrets. Brucellae can survive up to 15-25 days on a pasture depending on environmental conditions e.g. intensity of UV-light [31]. It is likely that the Egyptian Baladi goats and sheep which had aborted had contact with either the fetus or infective fluids from cattle abortion. Isolation of B. abortus DNA from a doe that aborted corroborates a cross-species transmission of the Brucella spp. 
Table 2 Serology and real-time PCR results of serum samples collected from animals, which had aborted recently and positive in at least one test

\begin{tabular}{|c|c|c|c|c|c|c|c|c|}
\hline \multirow[t]{2}{*}{ Case no. } & \multirow[t]{2}{*}{ Host } & \multirow{2}{*}{$\begin{array}{l}\text { History of samples } \\
\text { collection after abortion (weeks) }\end{array}$} & \multicolumn{3}{|c|}{ Serological assay } & \multicolumn{3}{|l|}{$P C^{d}$} \\
\hline & & & $\mathrm{RBT}^{\mathrm{a}}$ & $\mathrm{CFT}^{\mathrm{b}}$ & ELISA $^{c}$ & Bcsp 31 & IS711 B.abortus & IS711 B. melitensis \\
\hline 1 & Cow & 4 & + & + & + & + & + & - \\
\hline 2 & Cow & 3 & + & + & + & + & + & - \\
\hline 3 & Cow & 6 & + & + & + & + & + & - \\
\hline 4 & Cow & 4 & + & + & + & + & + & - \\
\hline 5 & Cow & 3 & + & + & + & + & + & - \\
\hline 6 & Cow & 3 & + & + & + & + & + & - \\
\hline 7 & Cow & 6 & + & + & + & + & + & - \\
\hline 8 & Cow & 4 & + & + & + & + & + & - \\
\hline 9 & Cow & 4 & + & + & + & + & + & - \\
\hline 10 & Cow & 3 & + & + & + & + & + & - \\
\hline 11 & Buffalo & 4 & + & + & + & + & + & - \\
\hline 12 & Buffalo & 1 & - & - & - & + & + & - \\
\hline 13 & Buffalo & 1 & - & - & - & + & + & - \\
\hline 14 & Buffalo & 1 & - & - & - & + & + & - \\
\hline 15 & Buffalo & 1 & - & - & - & + & + & - \\
\hline 16 & Goat & 4 & + & + & + & + & + & - \\
\hline 17 & Goat & 3 & + & + & + & + & + & - \\
\hline 18 & Goat & 4 & + & + & + & + & + & - \\
\hline 19 & Goat & 1 & - & - & - & + & + & - \\
\hline 20 & Goat & 1 & - & - & - & + & + & - \\
\hline 21 & Goat & 1 & - & - & - & + & + & - \\
\hline 22 & Goat & 1 & - & - & - & + & + & - \\
\hline 23 & Goat & 1 & - & - & - & + & + & - \\
\hline 24 & Goat & 1 & - & - & - & + & + & - \\
\hline 25 & Sheep & 4 & + & + & + & + & + & + \\
\hline \multicolumn{3}{|c|}{ Total positive } & 15 & 15 & 15 & 25 & 25 & 1 \\
\hline
\end{tabular}

a Considered positive when showing any degree of agglutination.

b Positive samples ( $\geq 20 \mathrm{IU} / \mathrm{ml}$ ).

c positive samples showing cut off values $(\geq 2)$.

d Positive samples showing ct value (ct $\leq 40$ ).

\section{Conclusion}

In summary, clinical presentation i.e. abortion and presence of Brucella DNA finally led to the diagnosis of brucellosis caused by B. abortus in Egyptian Baladi does (Capra hircus) and sheep (Ovis orientalis aries). To the best of our knowledge, our study is the first record on brucellosis caused by B. abortus in small ruminants in Egypt. Our findings indicate also that, in endemic areas like Egypt, where both Brucella spp. are present and small ruminants are raised with cattle in close contact in the same pasture, transmission of host specific Brucella species to non-preferred hosts may occur. These results should be taken in account while assessing the epidemiological situation in an area and during implementation of control measures. Trials to isolate the bacteria and molecular typing such as multi-locus variable number of tandem repeats (MLVA) to obtain an epidemiological evidence of transmission between animals is required.

\section{Abbreviations}

RT-PCR: real-time polymerase chain reaction; RBT: rose bengal test; CFT: complement fixation test; ELISA: enzyme linked immunosorbent assay; MLVA: multi-locus variable number of tandem repeats analysis.

\section{Authors' contribution}

GW designed and conceived the study, carried out the experimental work, data analysis, writing of the manuscript and helped to draft and review the manuscript. FM participates in serological assays, take part in writing of the manuscript, helped to draft the manuscript. HT participates in PCR assays and helped to draft the manuscript. UR and HN participated in the design, coordination of the study and evaluation of the results. All authors read and approved the final manuscript. 


\section{Author details}

${ }^{1}$ Friedrich-Loeffler-Institut, Federal Research Institute for Animal Health, Institute of Bacterial Infections and Zoonoses, Naumburger Str. 96a, 07743 Jena, Germany. ${ }^{2}$ Institute of Animal Hygiene and Environmental Health, Free University of Berlin, Robert-von-Ostertag Str. 7-13, 14163 Berlin, Germany. ${ }^{3}$ Department of Pathology, Faculty of Veterinary Medicine, Benha University, Qalyobia, Egypt.

\section{Acknowledgements}

We would like to thank Deutscher Akademischer Austausch Dienst (DAAD) and the Egyptian Ministry of Higher Education for financial support for GW Grant no. A/11/92495. The funders had no role in study design, data collection and analysis, decision to publish, or preparation of the manuscript.

\section{Compliance with ethical guidelines}

\section{Competing interests}

None of the authors of this paper has a financial or personal relationship with other people or organizations that could inappropriately influence or bias the content of the paper. The authors declare that they have no competing interests.

Received: 6 March 2015 Accepted: 15 May 2015

Published online: 03 June 2015

\section{References}

1. Aparicio ED (2013) Epidemiology of brucellosis in domestic animals caused by Brucella melitensis, Brucella suis and Brucella abortus. Rev sci tech Off int Epiz 32(1):53-60

2. Corbel M, Brinley MW (1984) Genus Brucella. In: Krieg NR, Holt JG (eds) Bergey's manual of systematic bacteriology. Williams \& Wilkins, Baltimore

3. Foster G, Osterman B, Godfroid J, Jacques I, Cloeckaert A (2007) Brucella ceti sp. nov. and Brucella pinnipedialis sp. nov. for Brucella strains with cetaceans and seals as their preferred hosts. Int J Syst Evol Microbiol 57:2688-2693

4. Scholz H, Hubalek Z, Sedlácek I, Vergnaud G, Tomaso H, Al Dahouk S et al (2008) Brucella microti sp. nov. isolated from the common vole Microtus arvalis. Int J Syst Evol Microbiol 58:375-382

5. Scholz H, Nöckler K, Gollner C (2010) Brucella inopinata sp. nov., isolated from a breast implant infection. Int J Syst Evol Microbiol 60:801-808

6. Whatmore A, Davison N, Cloeckaert A, Al Dahouk S, Zygmunt M, Brew S et al (2014) Brucella papionis sp. nov. isolated from baboons (Papio spp.). Int J Syst Evol Microbiol 64(Pt 12):4120-4128. doi:10.1099/ijs.0.065482-0 (Epub 2014 Sep 21)

7. Holt HR, Eltholth MM, Hegazy YM, El-Tras WF, Tayel AA, Guitian J (2011) Brucella spp. infection in large ruminants in an endemic area of Egypt: cross-sectional study investigating seroprevalence, risk factors and livestock owner's knowledge, attitudes and practices (KAPs). BMC Public Health 11:341. doi:10.1186/1471-2458-11-341

8. Samaha H, Al-Rowaily M, Khoudair RM, Ashour HM (2008) Multicenter study of brucellosis in Egypt. Emerg Infect Dis 14(12):1916-1918

9. El-Tras W, Tayel A, Eltholth M, Guitian J (2010) Brucella infection in fresh water fish: evidence for natural infection of Nile catfish, Clarias gariepinus, with Brucella melitensis. Vet Microbiol 141:321-325

10. Refai M (2002) Incidence and control of brucellosis in the Near East region. Vet Microbiol 90:81-110

11. El-Seedy F, Radwan A, El-Shabrawy M (2000) Serological and bacteriological investigations on Brucella infection in one humped camels (Camelus dromedarius) in Egypt. Vet Med J Giza 48:83-89

12. Hamdy MER, Amin AS (2002) Detection of Brucella species in the milk of infected cattle, sheep, goats and camels by PCR. Vet J 163:299-305

13. Wareth G, Hikal A, Refai M, Melzer F, Roesler U, Neubauer H (2014) Animal brucellosis in Egypt. J Infect Dev Ctries 8(11):1365-1373. doi:10.3855/ jidc.4872

14. Probert WS, Schrader KN, Khuong NY, Bystrom SL, Graves MH (2004) Realtime multiplex PCR assay for detection of Brucella spp., B. abortus, and B. melitensis. J Clin Microbiol 42(3):1290-1293
15. Bercovich Z (1998) Maintenance of Brucella Abortus-free herds: a review with emphasis on the epidemiology and the problems in diagnosing brucellosis in areas of low prevalence. Vet Q 20(3):81-88

16. Poester FP, Nielsen K, Samartino LE, Yu WL (2010) Diagnosis of brucellosis. Open Vet Sci 4:46-60

17. Marianelli C, Martucciello A, Tarantino M, Vecchio R, lovane G, Galiero G (2008) Evaluation of molecular methods for the detection of Brucella species in water buffalo milk. J Dairy Sci 91:3779-3786

18. Junqueira JD, Rosinha G, Carvalho C, Oliveira C, Sanches C, Lima-Ribeiro A (2013) Detection of Brucella spp. DNA in the semen of seronegative bulls by polymerase chain reaction. Transbound Emerg Dis 60(4):376-377

19. Martirosyan A, Moreno E, Gorvel J-P (2011) An evolutionary strategy for a stealthy intracellular Brucella pathogen. Immunol Rev 240(1):211-234

20. Gorham SL, Enright FM, Snider TG 3rd, Roberts ED (1986) Morphologic lesions in Brucella abortus infected ovine fetuses. Vet Pathol 23(3):331-332

21. Kreeger T, Cook W, Edwards W, Cornish T (2004) Brucellosis in captive Rocky Mountain bighorn sheep (Ovis canadensis) caused by Brucella abortus biovar 4. J Wildl Dis 40(2):311-315

22. Ocholi R, Kwaga J, Ajogi I, Bale J (2005) Abortion due to Brucella abortus in sheep in Nigeria. Rev Sci Tech 24(3):973-979

23. Okoh A (1980) Abortion in sheep near Kano, Nigeria. Trop Anim Health Prod 12(1):11-14

24. Behroozikhah A, Bagheri NR, Amiri K, Bahonar A (2012) Identification at biovar level of Brucella isolates causing abortion in small ruminants of Iran. J Pathog. doi:10.1155/2012/357235

25. Fosgate GT, Diptee MD, Ramnanan A, Adesiyun AA (2011) Brucellosis in domestic water buffalo (Bubalus bubalis) of Trinidad and Tobago with comparative epidemiology to cattle. Trop Anim Health Prod 43(8):1479-1486

26. Gomo C, de Garine-Wichatitsky M, Caron A, Pfukenyi DM (2012) Survey of brucellosis at the wildlife-livestock interface on the Zimbabwean side of the great Limpopo transfrontier conservation area. Trop Anim Health Prod 44(1):77-85

27. Salem A, Hosein H (1990) Brucella strains prevalent in Egypt. Assiut Vet Med J 22:160-163

28. Amin A, Hamdy M, Ibrahim A (2001) Detection of Brucella melitensis in semen using the polymerase chain reaction assay. Vet Microbiol 83:37-44

29. Samaha H, Mohamed TR, Khoudair RM, Ashour HM (2009) Serodiagnosis of brucellosis in cattle and humans in Egypt. Immunobiology 214:223-226

30. Wareth G, Melzer F, Elschner MC, Neubauer H, Roesler U (2014) Detection of Brucella melitensis in bovine milk and milk products from apparently healthy animals in Egypt by real-time PCR. J Infect Dev Ctries 8(10):13391343. doi:10.3855/jidc.4847

31. Richomme C, Gauthier D, Fromont E (2006) Contact rates and exposure to inter-species disease transmission in mountain ungulates. Epidemiol Infect 134(1):21-30

\section{Submit your next manuscript to BioMed Central and take full advantage of:}

- Convenient online submission

- Thorough peer review

- No space constraints or color figure charges

- Immediate publication on acceptance

- Inclusion in PubMed, CAS, Scopus and Google Scholar

- Research which is freely available for redistribution 